\title{
Pengaruh Fraksi Massa Serat Terhadap Kekuatan Fatik Material Komposit Berpenguat Serat Tandan Kosong Kelapa Sawit
}

\author{
Devi Chandra $^{a}$, Randha Mulia $^{b}$, Dedison Gasni ${ }^{a}$, Gusriwandi $^{a}$ \\ ${ }^{a}$ Jurusan Teknik Mesin, Fakultas Teknik, Universitas Andalas, Padang, 25643, Indonesia \\ ${ }^{b}$ Mahasiswa Jurusan Teknik Mesin, Fakultas Teknik, Universitas Andalas, Padang, 25643, Indonesia
}

INFORMASI ARTIKEL

\section{Sejarah Artikel:}

Diterima Redaksi: 8 September 2018

Revisi Akhir: 24 September 2018

Diterbitkan Online: 29 Oktober 2018

\section{KATA KUNCI}

Kekuatan fatik

Material komposit

Serat sawit

Fraksi massa

KORESPONDENSI

E-mail: devichandra@ft.unand.ac.id

\begin{abstract}
A B S T R A C T
The present study was investigated the effect of fiber mass fraction on the tensile and fatigue strength of oil palm fiber reinforced composite and resin as the matrix. Fatigue test has been performed by using rotary bending fatigue machine. The specimens were made by press hand lay-up with matrix to fiber mass ratio was 90:10, 80:20 and 70:30 respectively. Fracture surface of fatigue specimens have also been observed by using digital camera to knowing the failure mode. The results showed that the tensile and fatigue strength and fatigue life increased with increasing the fiber mass fraction as seen in the S-N curve. The fatigue limit was found $0.27 \mathrm{MPa}, 0.55 \mathrm{MPa}$, and 0.82 MPa for composites with 90:10, 80:20 and 70:30 of matrix to fiber mass ratio respectively. The observed failure modes were matrix cracking, fiber debonding, and fiber breaking.
\end{abstract}

\section{PENDAHULUAN}

Material komposit telah digunakan untuk pembuatan komponen konstruksi diberbagai bidang seperti sipil, militer, penerbangan, otomotif, energi angin, biomedik dsb. Permintaan oleh dunia industri terhadap material ini semakin meningkat karena sifat-sifatnya yang lebih baik dibandingkan material logam seperti berat spesifik yang rendah, biaya produksi yang murah serta lebih mudah untuk dibuat. Akhir-akhir ini, material komposit yang terbuat dari gabungan serat bahan alam dan polimer lebih cenderung dipilih sebagai material alternatif pengganti material komposit sintetis yang seratnya terbuat dari serat carbon, serat kaca dsb. Alasanya adalah karena komposit serat bahan alam dinilai lebih ramah lingkungan dan bahan seratnya lebih banyak tersedia seperti serat kelapa sawit, serat nenas, serat rami, serat enau dsb.

Terjadinya kegagalan pada komponen struktur teknik banyak disebabkan oleh beban berulang atau beban fatik. Sebagai contoh sebuah poros yang mendapat beban berulang dapat patah lelah pada suatu periode waktu tertentu. Patah lelah akan lebih berbahaya dari patah statis karena dia terjadi secara tiba-tiba tanpa peringatan terlebih dahulu.

Kajian terhadap kekuatan fatik material logam secara eksperimen dan numerik sudah banyak dikemukakan diberbagai literature dan hasilnya banyak digunakan sebagai acuan dalam perancangan struktur teknik yang terintegrasi. Namun kajian tentang kekuatan fatik material komposit cukup jarang dijumpai terutama material 
komposit yang terbuat dari serat bahan alam seperti serat tandan kosong kelapa sawit. Apabila sebuah komponen mekanis yang dibebani berulang akan dibuat dari material komposit berserat kelapa sawit, maka sifat fatik dari material ini harus diketahui terlebih dahulu. Sehingga mengetahui kekuatan fatik material komposit dengan serat tandan kosong sawit menjadi objek penelitian yang cukup penting agar material ini dapat dipertimbangkan untuk dipilih dalam proses desain.

\section{TINJAUAN PUSTAKA}

Penggunaan material komposit di dunia industri mengalami perkembangan pesat seiring dengan kemajuan ilmu pengetahuan dan teknologi. Panel komposit dari serat alam sudah digunakan pada mobil Toyota di Jepang dan mobil Mercedes Benz di Jerman. Produsen otomotif Daimler Chrysler adalah industri yang paling banyak menggunakan serat alam sebagai material penguat komposit polimer terutama untuk bahan eksterior dan interior mobil. Setelah ditemukannya serat sintetis yang dibuat secara kimiawi, akhir-akhir ini para ilmuwan beralih melakukan penelitian pada material komposit yang terbuat dari serat alam yang relatif lebih murah dan mudah didapatkan dibanding komposit sintetis serta dapat terurai secara alami dan tidak beracun [1]. Ilmuwan mulai meneliti sifat-sifat alami dan melakukan uji mekanis terhadap serat - serat alam yang ada seperti serat tanda kosong kelapa sawit (TKKS), serat nenas, serat eceng gondok, dsb.

Penggunaan material komposit untuk pembuatan komponen mesti mempertimbangkan kemampuan material tersebut untuk menahan semua kondisi kerja termasuk kondisi adanya beban dinamik atau beban lelah. Kelelahan memegang peranan utama dalam putusnya komponen pada suatu struktur yang menerima beban dinamis. Sebahagian besar $(70 \%$ - 80\%) kegagalan pada elemen mesin disebabkan oleh beban dinamik. Jenis kegagalan itu terjadi pada tingkat tegangan yang signifikan lebih rendah dari tegangan yield material [2]. Patah yang disebabkan kelelahan melalui beberapa tahapan; dimulai dari terjadinya retak awal (initial crack), perambatan retak lelah dan akhirnya patah statis (final fracture). Pengujian kelelahan material menghasilkan data dalam bentuk diagram Wohler atau lebih dikenal dengan kurva S-N yang menyatakan hubungan level tegangan yang dialami material dengan jumlah siklus tegangan ketika patah terjadi. Salah satu cara untuk mengetahui sifat-sifat kelelahan material adalah dengan uji lelah menggunakan mesin uji lelah lentur-putar, Moore [3].

Kekuatan lelah material dipengaruhi oleh beberapa faktor seperti konsentrasi tegangan, ukuran material, kualitas permukaan material, perlakuan permukaan, temperatur dan lingkungan. Data kekuatan lelah material biokomposit sangat sedikit sekali tersedia sehingga penelitian terus dilakukan oleh para peneliti. Diantara peneliti dimaksud adalah Haque [6] yang telah meneliti keandalan dan terjadinya kerusakan pada komposit serat keramik karena beban lelah pada temperature kamar dan temperature tinggi. Ogawa [7] meneliti perambatan retak permukaan material karena beban lelah lentur-putar. Khashaba [8] meneliti sifat lelah dan keandalan dari GFRP komposit menggunakan mesin uji lelah lentur putar. Haftirman [9] meneliti kekuatan lelah baja pada lingkungan dengan kelembaban tinggi. Alaya [10] mengkaji pengaruh kedalaman takik ulir metris terhadap kekuatan lelah Baja Karbon Rendah. Reylan [11] meneliti pengaruh lama waktu perlakuan Alkali terhadap kekuatan bending komposit papan serat tandan kosong kelapa sawit. Alisa [12] meneliti perilaku perambatan retak pada material komposit resin dan silica partikel. Bizeul [13] meneliti perilaku perambatan retak karena beban tarik pada material komposit serat glass.

\section{METODOLOGI}

\subsection{Bahan Komposit}

Material komposit yang menjadi objek kajian terbuat dari serat tandan kosong kelapa sawit sebagai penguat dan resin polyester sebagai matrik atau pengikat. Bahan serat dalam bentuk setengah jadi diperoleh dari pabrik pengolahan kelapa sawit di Kinali Kab. Pasaman, Sumatera Barat, sedangkan resin polyester yang diproduksi oleh PT. Justus Sakti Raya dengan merek Yukalac 
didapat dari pemasok. Bentuk serat dan sifat mekanik resin polyester diperlihatkan berturutturut pada Gambar 1 dan Tabel 1.

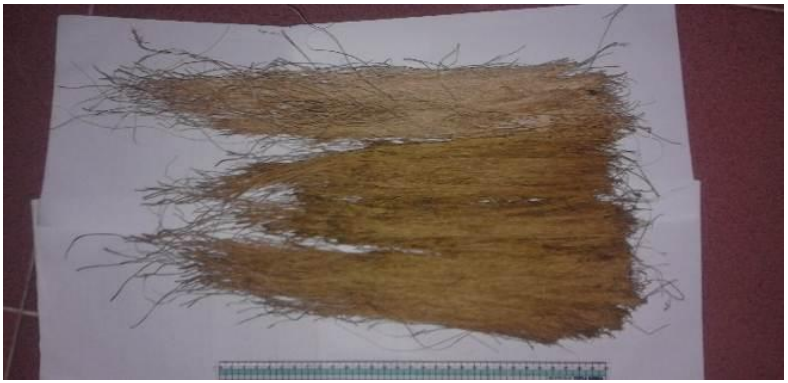

Gambar 1. Serat Tandan Kosong Kelapa Sawit

Tabel 1. Sifat Mekanik Resin Polyester

\begin{tabular}{l|l|l}
\hline \multicolumn{1}{c|}{ Sifat } & \multicolumn{1}{c|}{ Nilai } & \multicolumn{1}{c}{ Satuan } \\
\hline Berat Jenis & 1215 & $\mathrm{~kg} / \mathrm{m}^{3}$ \\
\hline kekuatan tarik & 5,5 & $\mathrm{~kg} / \mathrm{mm}^{2}$ \\
\hline kekuatan flexural & 9,4 & $\mathrm{~kg} / \mathrm{mm}^{2}$ \\
\hline modulus elastisitas & 300 & $\mathrm{~kg} / \mathrm{mm}^{2}$ \\
\hline Elongation & 1,6 & $\%$ \\
\hline
\end{tabular}

Untuk mempercepat proses pengerasan dan pengeringan resin polyester, kedalam resin ditambahkan hardener yaitu Methyl Ethyl Keton Peroxida (Mekpo). Hardener ini berupa cairan berwarna bening yang diproduksi oleh PT. Justus Kimia Raya. Karena berpengaruh terhadap tingkat kegetasan material komposit, maka pemakaian hardener ini dibatasi sampai $1 \%$ dari volume resin yang digunakan.

\subsection{Penyiapan Serat}

Sebelum dipotong sesuai dengan panjang cetakan, serat dikeringkan dibawah cahaya matahari dan dengan menggunakan hair dryer. Selanjutnya dilakukan proses Alkalisasi pada serat menggunakan larutan $\mathrm{NaOH} 7,5 \%$ selama 60 menit. Setelah proses Alkalisasi, serat lalu dicuci pada air yang mengalir selama \pm 10 menit, dan direndam di dalam wadah yang berisi air selama \pm 30 menit sehingga $\mathrm{NaOH}$ pada serat hilang semuanya.

\subsection{Pembuatan Spesimen}

\subsubsection{Spesimen Uji Fatik}

Resin polyester dan hardener dicampur dan diaduk dalam sebuah wadah dengan perbandingan 100:1. Campuran ini yang berfungsi sebagai penguat (matrik) dituang kedalam cetakan yang berukuran panjang $100 \mathrm{~mm}$ dan diameter dalam $11 \mathrm{~mm}$ seperti terlihat pada Gambar 2. Selanjutnya serat yang sudah ditimbang beratnya dimasukan secara acak kedalam cetakan yang berisi penguat (matrik) dengan posisi memanjang searah sumbu cetakan. Setelah dingin dan dikeluarkan dari cetakan, material komposit kemudian di machining menggunakan mesin bubut untuk memperoleh specimen uji lelah seperti terlihat pada Gambar 4. Spesimen uji lelah ini dibuat mengacu kepada standar BS3691 dengan dimensi dan geometri seperti pada Gambar 3.

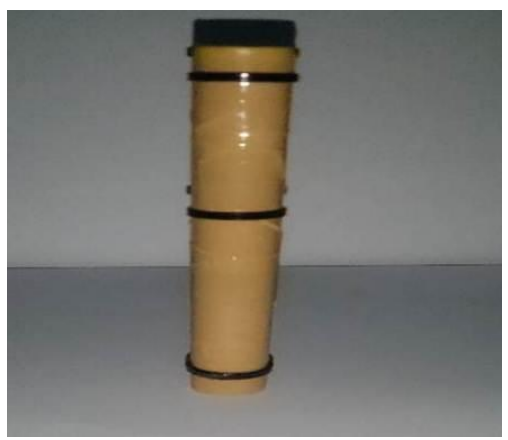

Gambar 2. Cetakan Spesimen Uji Fatik

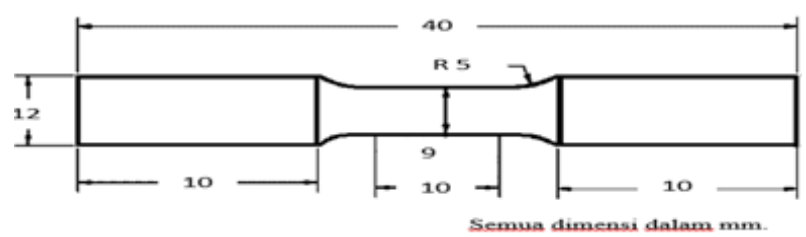

Gambar 3. Dimensi Specimen Uji Fatik Komposit Menurut BS3691

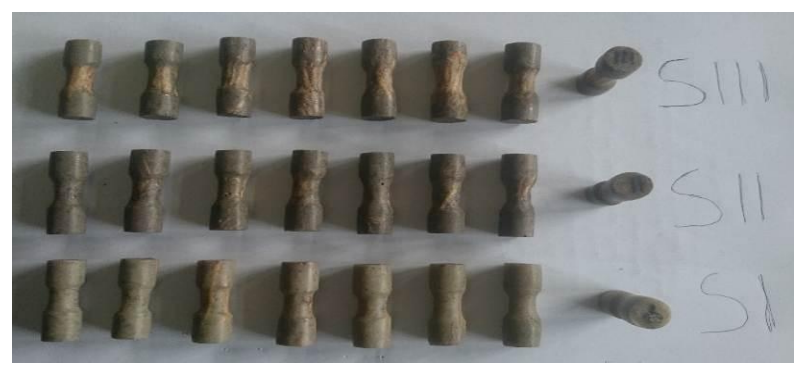

Gambar 4. Spesimen Uji Fatik Komposit Serat Tandan Kosong Kelapa Sawit 


\subsubsection{Spesimen Uji Tarik}

Untuk membuat specimen uji tarik, campuran resin polyester dan hardener seperti dijelaskan pada bagian 3.3.1 dituang kedalam cetakan. Selanjutnya serat yang sudah ditimbang beratnya dimasukan kedalam cetakan yang berisi penguat (matrik) dengan posisi memanjang searah sumbu cetakan. Setelah dingin dan dikeluarkan dari cetakan akan diperoleh sampel material komposit berukuran panjang $175 \mathrm{~mm}$, lebar $25 \mathrm{~mm}$ dan tebal $2 \mathrm{~mm}$. Selanjutnya sampel digerinda dan diamplas pada kedua sisinya untuk mendapatkan specimen sesuai dengan standar ASTM D3039 dengan bentuk dan ukuran seperti pada Gambar 5. Gambar 6 memperlihatkan hasil spesimen uji tarik komposit serat tandan kosong sawit yang dibuat berdasarkan standar ASTM D3039.

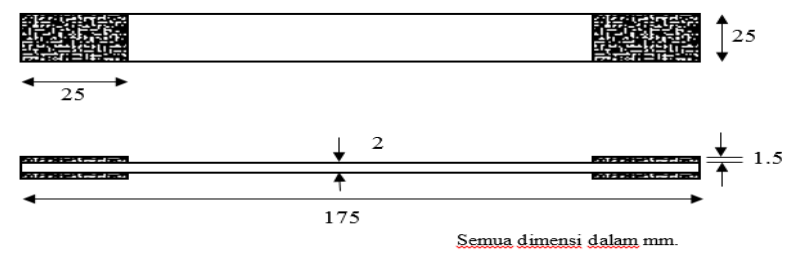

Gambar 5. Dimensi Spesimen Uji Fatik Komposit Menurut ASTM D3039

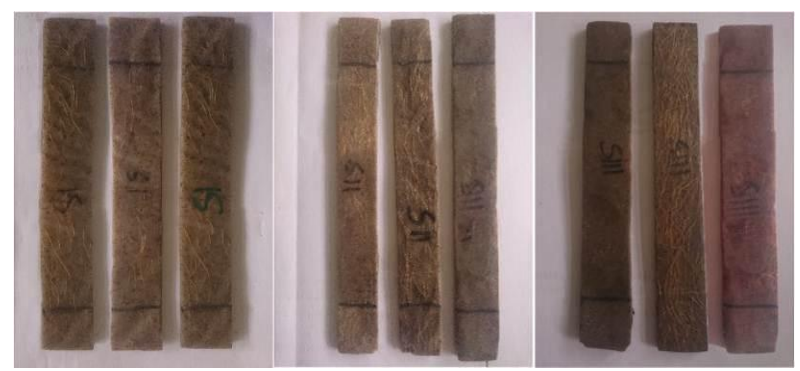

Gambar 6. Spesimen Uji Tarik Komposit Serat Tandan Kosong Kelapa Sawit

\subsection{Pengujian Kekuatan Tarik}

Pengujian tarik komposit berpenguat serat tandan kosong kelapa sawit bertujuan untuk mengetahui nilai kekuatan tarik maksimum (ultimate tensile strength) dari komposit. Nilai kekuatan tarik maksimum ini dijadikan dasar dalam menentukan beban pada pengujian fatik. Pengujian tarik dilakukan menggunakan Mesin Uji Tarik (Universal Testing Machine) yang ada di
Laboratorium Jurusan Teknik Mesin Universitas Andalas.

\subsection{Pengujian Kekuatan Fatik}

Pengujian fatik dilakukan menggunakan Mesin Uji Fatik Rotating Bending yang ada di Laboratorium Jurusan Teknik Mesin Universitas Andalas seperti terlihat pada Gambar 7 dan 8. Mula-mula spesimen uji fatik dipasangkan pada mesin uji fatik, lalu beban pada mesin diseting sesuai dengan variasi beban yang direncanakan. Selanjutnya mesin uji fatik dihidupkan sehingga spesimen akan berputar dan mengalami tegangan tarik-tekan berulang akibat beban bending putar. Ketika spesimen mengalami kegagalan (patah), mesin uji dimatikan dan jumlah siklus pembebanan yang menunjukan umur lelah dicatat dari pencatat (counter) mesin. Proses ini dilakukan berulang untuk berbagai variasi beban yang diinginkan.

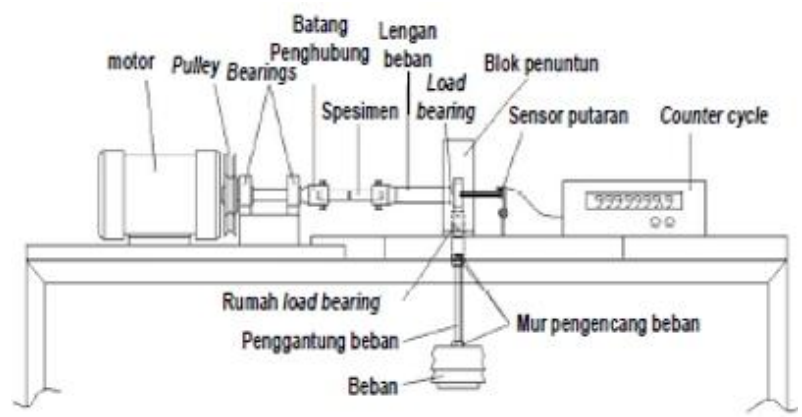

Gambar 7. Skematik Mesin Uji Fatik Rotating Bending

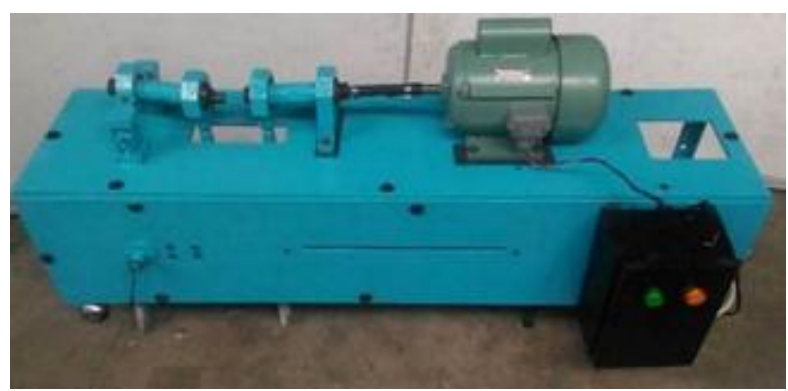

Gambar 8. Mesin Uji Fatik Rotary Bending

\subsection{Pengamatan Permukaan Patahan}

Permukaan patahan specimen uji fatik diamati menggunakan kamera digital. Pengamatan bertujuan untuk mengetahui bentuk dan mekanisme gagal fatik pada material komposit serat acak tandan kelapa sawit. 


\section{HASIL DAN PEMBAHASAN}

\subsection{Kekuatan Tarik Komposit}

Pengujian tarik dilakukan untuk sebanyak 45 spesimen yaitu 15 spesimen untuk masing-masing variasi serat komposit. Hasil uji tarik material komposit serat tandan kosong kelapa sawit dengan variasi massa serat 1, 2, dan 3 gram ditunjukan pada Tabel 2, dimana semakin besar massa serat maka semakin tinggi nilai kekuatan tarik material.

Tabel 2. Hasil Uji Tarik Komposit

\begin{tabular}{c|c|c}
\hline No & $\begin{array}{c}\text { Variasi } \\
\text { Serat }\end{array}$ & $\begin{array}{c}\text { Kekuatan Tarik Maksimum } \\
\text { Rata-rata }(\mathrm{MPa})\end{array}$ \\
\hline 1 & SI $(1$ gram $)$ & 24.9 \\
\hline 2 & SII $(2$ gram $)$ & 28.6 \\
\hline 3 & SIII $(3$ gram $)$ & 38.2 \\
\hline
\end{tabular}

\subsection{Kekuatan Fatik Komposit}

Sebelum dilakukan pengujian lelah terlebih dahulu dicari berapa pembebanan yang digunakan berdasarkan kepada tegangan ultimate yang telah didapatkan dari hasil uji tarik. Untuk mendapatkan besarnya pembebanan maka tegangan ultimate tersebut dimasukan kedalam persamaan 1, sehingga nilai-nilai pembebanan yang diberikan dapat dilihat pada Tabel 3.

$$
W=\frac{\sigma \cdot \pi \cdot d^{3}}{l \cdot 16}
$$

Pengujian lelah dilakukan untuk mengetahui kekuatan lelah dari komposit serat TKKS, Harga Kekuatan lelah TKKS diperoleh melalui mesin uji lelah lentur putar dengan memberi beban bending pada spesimen secara bertahap dari pembebanan tinggi sampai dengan pembebanan rendah, dan kemudian diputar sampai spesimen gagal/patah. Hasil pengujian lelah komposit serat TKKS dengan variasi serat 1,2, 3 gram dapat dilihat pada Tabel 4.

Dari Tabel 4 dapat dilihat nilai siklus dari ketiga fraksi massa serat berdasarkan pembebanan yang diberikan. Untuk spesimen SI dengan komposisi serat TKKS dengan farksi massa sebanyak 10\% (1 gram), maka pada pembebanan $9 \%$ dari tegangan tarik yaitu 2.24 MPa diperoleh umur lelah material sebesar 12960 siklus sedangkan pada pembebanan lebih rendah (3\% dari tegangan tarik) yaitu 0,75 MPa diperoleh umur lelah material sebesar 218165 siklus.

Tabel 3. Nilai Pembebanan Pada Uji Fatik.

\begin{tabular}{|c|c|c|c|c|}
\hline No & Spesimen & $\% \times \mathrm{UTS}$ & $\begin{array}{c}\text { UTS } \\
(\mathrm{MPa})\end{array}$ & $\begin{array}{c}\text { W (beban) } \\
\mathrm{kg}\end{array}$ \\
\hline \multirow{4}{*}{1} & \multirow{4}{*}{ SI } & 9 & \multirow{4}{*}{24.89} & 0.82 \\
\hline & & 7 & & 0.64 \\
\hline & & 5 & & 0.45 \\
\hline & & 3 & & 0.27 \\
\hline \multirow{4}{*}{2} & \multirow{4}{*}{ SII } & 9 & \multirow{4}{*}{28.60} & 0.94 \\
\hline & & 7 & & 0.73 \\
\hline & & 5 & & 0.52 \\
\hline & & 3 & & 0.31 \\
\hline \multirow{4}{*}{3} & \multirow{4}{*}{ SIII } & 9 & \multirow{4}{*}{38.21} & 1.25 \\
\hline & & 7 & & 0.98 \\
\hline & & 5 & & 0.70 \\
\hline & & 3 & & 0.42 \\
\hline
\end{tabular}

Tabel 4. Data Hasil Pengujian Fatik

\begin{tabular}{|c|c|c|c|c|}
\hline No & Spesimen & $\begin{array}{c}\text { Tegangan } \\
\text { (MPa) }\end{array}$ & $\begin{array}{l}\text { Pembebanan } \\
(\mathrm{kg})\end{array}$ & $\begin{array}{c}\text { Umur } \\
\text { (Siklus) }\end{array}$ \\
\hline \multirow{5}{*}{1} & \multirow{5}{*}{ SI } & 2.24 & 0.82 & 12960 \\
\hline & & 1.74 & 0.64 & 106650 \\
\hline & & 1.24 & 0.45 & 161325 \\
\hline & & 0.75 & 0.27 & 218565 \\
\hline & & 0.27 & 0.1 & 1083510 \\
\hline \multirow{5}{*}{2} & \multirow{5}{*}{ SII } & 2.62 & 0.94 & 33345 \\
\hline & & 2.04 & 0.73 & 209250 \\
\hline & & 1.45 & 0.52 & 234225 \\
\hline & & 0.87 & 0.31 & 260550 \\
\hline & & 0.55 & 0.2 & 1009800 \\
\hline \multirow{5}{*}{3} & \multirow{5}{*}{ SIII } & 3.57 & 1.25 & 163350 \\
\hline & & 2.77 & 0.98 & 270135 \\
\hline & & 1.98 & 0.70 & 355860 \\
\hline & & 1.19 & 0.42 & 436725 \\
\hline & & 0.82 & 0.3 & 1023840 \\
\hline
\end{tabular}

Fatik limit untuk spesimen ini didapatkan sebesar $0.27 \mathrm{MPa}$ dimana pada tegangan ini jumlah siklus pembebanan telah melebihi $10^{6}$ dan spesimen tidak mengalami kegagalan. Untuk spesimen SII dengan komposisi serat tandan kosong kelapa sawit 
(TKKS) dengan fraksi massa sebanyak 20\% (2 gram), pada pembebanan $9 \%$ dari tegangan tarik yaitu 2.62 MPa diperoleh umur lelah material sebesar 33345 siklus, sedangkan pada pembebanan lebih rendah (3\% dari tegangan tarik) yaitu 0,87 MPa diperoleh umur lelah material sebesar 260550 siklus. Fatik limit untuk spesimen ini didapatkan sebesar $0.55 \mathrm{MPa}$ dimana pada tegangan ini jumlah siklus pembebanan telah melebihi $10^{6}$ siklus dan spesimen tidak mengalami kegagalan.

Untuk spesimen SIII dengan komposisi serat TKKS dengan farksi massa sebanyak 30\% (3 gram), pada pembebanan $9 \%$ dari tegangan tarik yaitu 3.57 MPa diperoleh umur lelah material sebesar 163350 siklus sedangkan pada pembebanan lebih rendah (3\% dari tegangan tarik) yaitu 1.19 MPa diperoleh umur lelah material sebesar 436725 siklus. Fatik limit untuk spesimen ini didapatkan sebesar $0.82 \mathrm{MPa}$ dimana pada tegangan ini jumlah siklus pembebanan telah melebihi $10^{6}$ dan spesimen tidak mengalami kegagalan.

Setelah didapatkan data hasil pengujian, maka dibuatkan kedalam kurva $\mathrm{S}-\mathrm{N}$ seperti yang terlihat pada Gambar 9.

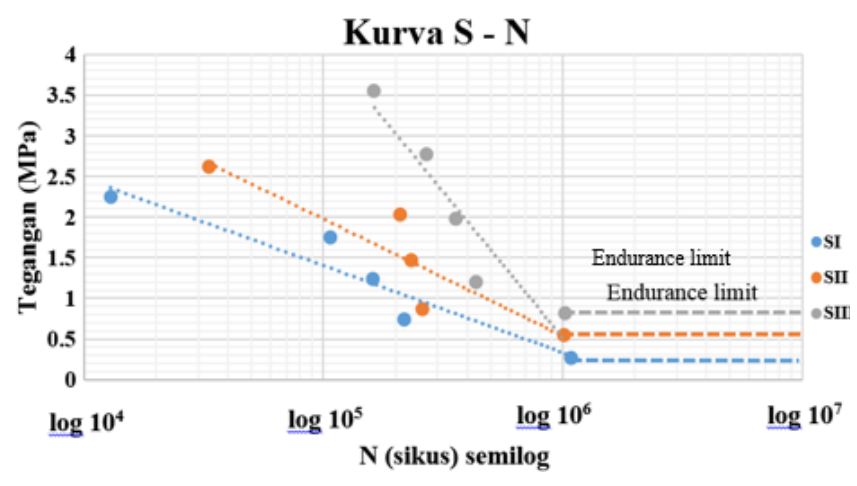

Gambar 9. Kurva S-N Hasil Pengujian Fatik

Dari gambar 9, pengujian lelah komposit serat TKKS dengan tiga variasi massa serat dapat diketahui bahwa nilai dari kekuatan fatik akan naik sebanding dengan komposisi serat yang terdapat didalam komposit TKKS, adapun variasi komposit dengan umur lelah terendah adalah spesimen SI (fraksi massa 10\% serat) yaitu 218565 siklus dan variasi komposit dengan umur lelah tertinggi adalah spesimen SIII (fraksi massa 30\% serat) yaitu 436725 siklus. Sedangkan untuk semua variasi komposit, umur lelah yang didapatkan berbanding terbalik dengan nilai pembebanan yang diberikan, semakin tinggi pembebanan yang diberikan maka semakin rendah umur lelah yang didapatkan dan sebaliknya semakin kecil pembebanan yang diberikan maka umur lelah akan semakin tinggi. Batas kekuatan lelah (endurance limit) didapatkan pada tegangan paling rendah pada kurva S-N, dimana pada kondisi ini spesimen yang diuji tidak mengalami kegagalan.

Untuk menentukan pengaruh fraksi volume dari massa spesimen uji lelah terhadap umur lelah, maka data yang telah didapatkan diatas dimasukan kedalam grafik seperti pada Gambar 10.

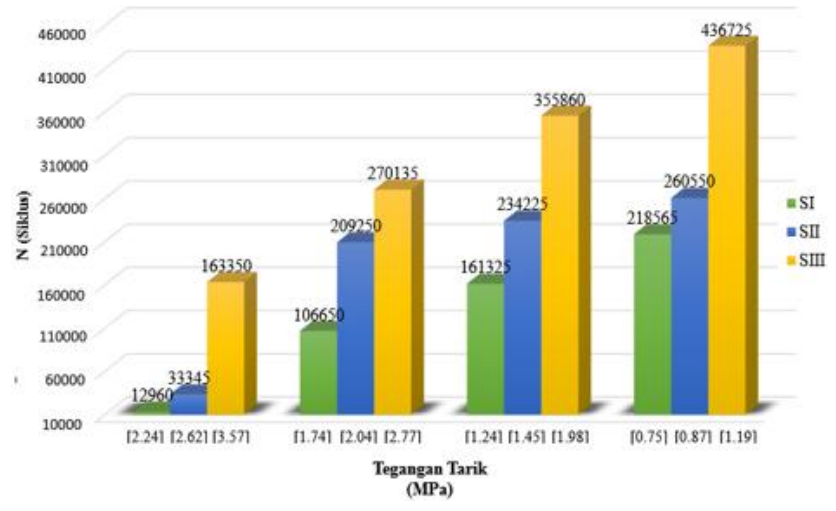

Gambar 10. Pengaruh fraksi volume terhadap umur lelah

Dari Gambar 10 dapat dilihat kenaikan dari variasi fraksi volume massa serat TKKS terhadap umur lelah yang didapatkan, dimana untuk semua variasi fraksi massa dari spesimen pengujian TKKS didapatkan bahwa serat TKKS mengalami peningkatan umur lelah dimana, semakin banyak fraksi massa serat TKKS yang terdapat pada komposit maka umur lelah akan semakin tinggi. Dalam pengujian ini spesimen uji lelah yang memiliki umur lelah yang tinggi adalah pada spesimen SIII sedangkan spesimen uji lelah yang memiliki umur lelah yang rendah adalah pada spesimen SI.

\subsection{Permukaan Patahan Uji Fatik}

Bentuk patahan lelah komposit serat TKKS dapat dianalisa pada antar muka spesimen yang telah mengalami lelah untuk berbagai variasi massa serat secara visual dengan menggunakan kamera 
digital. Bentuk patahan lelah komposit serat TKKS dapat dilihat pada Gambar 11-13.

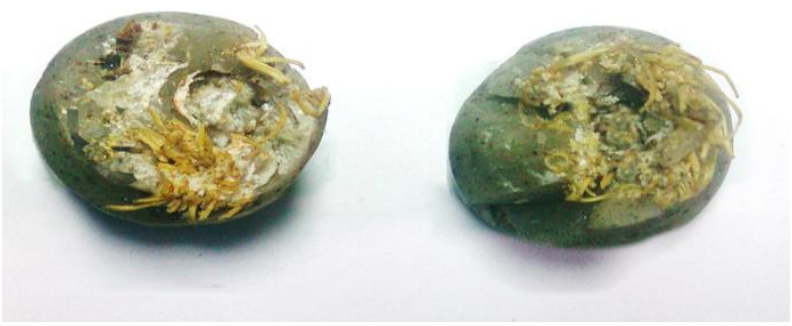

Gambar 11. Permukaan Patahan Spesimen SI

Gambar 11 memperlihatkan bentuk patahan antar muka spesimen SI dengan fraksi massa serat $10 \%$ (1 gram) pada pembebanan $0.75 \mathrm{MPa}(0.27 \mathrm{~kg})$. Gambar makro permukaan patahan memperlihatkan komposit setelah dilakukan pengujian, dimana pada patahan terdapat patahan berserabut yang dikaitkan dengan serat yang menjadi komposisi utama dari komposit TKKS, walaupun komposisi seratnya sedikit tapi dapat terlihat orientasi serat setelah patah seperti berputar (terpuntir) dan dari gambar terlihat terdapat zona patahan mengkilap relatif lebih kecil, patah mengkilap umumnya dimiliki sifat dari material yang getas, namun pada zona yang berwarna keputihan tidak terlihat patahan yang mengkilap, hal ini dapat dikaitkan dengan pertumbuhan retak yang berlangsung selama pengujian lentur putar sehingga terbentuklah ketidakstabilan yang mengakibatkan penampang spesimen tidak mampu menahan beban yang diberikan.

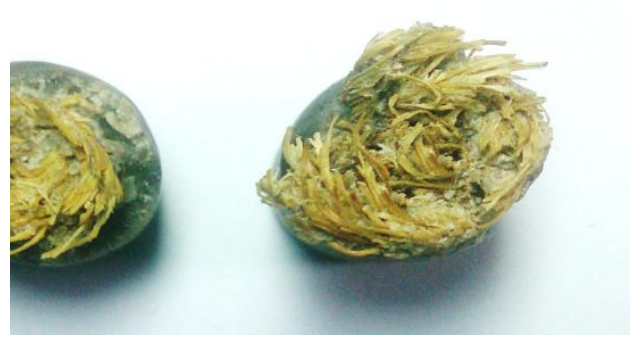

\section{Gambar 12. Permukaan Patahan Spesimen SII}

Gambar 12 memperlihatkan bentuk patahan antar muka spesimen SII dengan fraksi massa serat $2 \%$ (2 gram) pada pembebanan $0,87 \mathrm{MPa}(0.27 \mathrm{~kg})$, gambar makro permukaan patahan memperlihatkan komposit setelah dilakukan pengujian, dimana pada patahan terlihat jelas terdapat patah berserabut yang dikaitkan dengan serat yang menjadi komposisi utama dari komposit TKKS, pada spesimen SII ini juga terlihat jelas orientasi serat yang berputar setelah terjadi patahan.sedangkan untuk zona patahan mengkilap sangat kecil sekali hal ini dapat dikaitkan dengan banyak nya serat sehingga patah getas tidak terlihat jelas karena distribusi tegangan dari serat menghalangi terjadi nya patah getas.

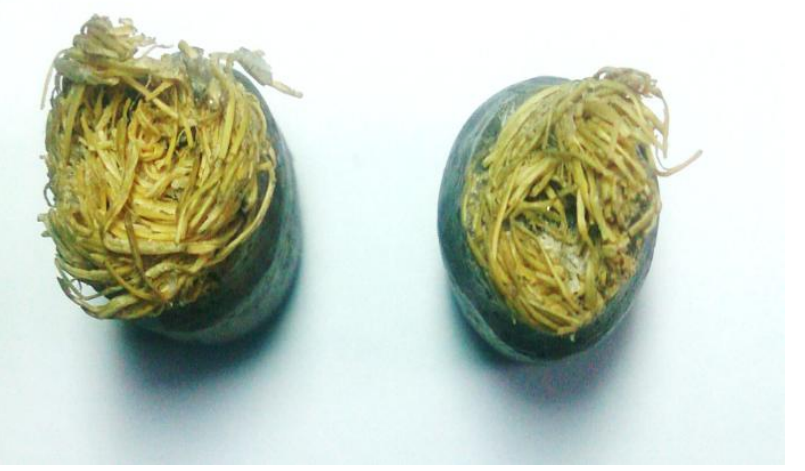

Gambar 13. Gambar 11. Permukaan Patahan Spesimen SIII 


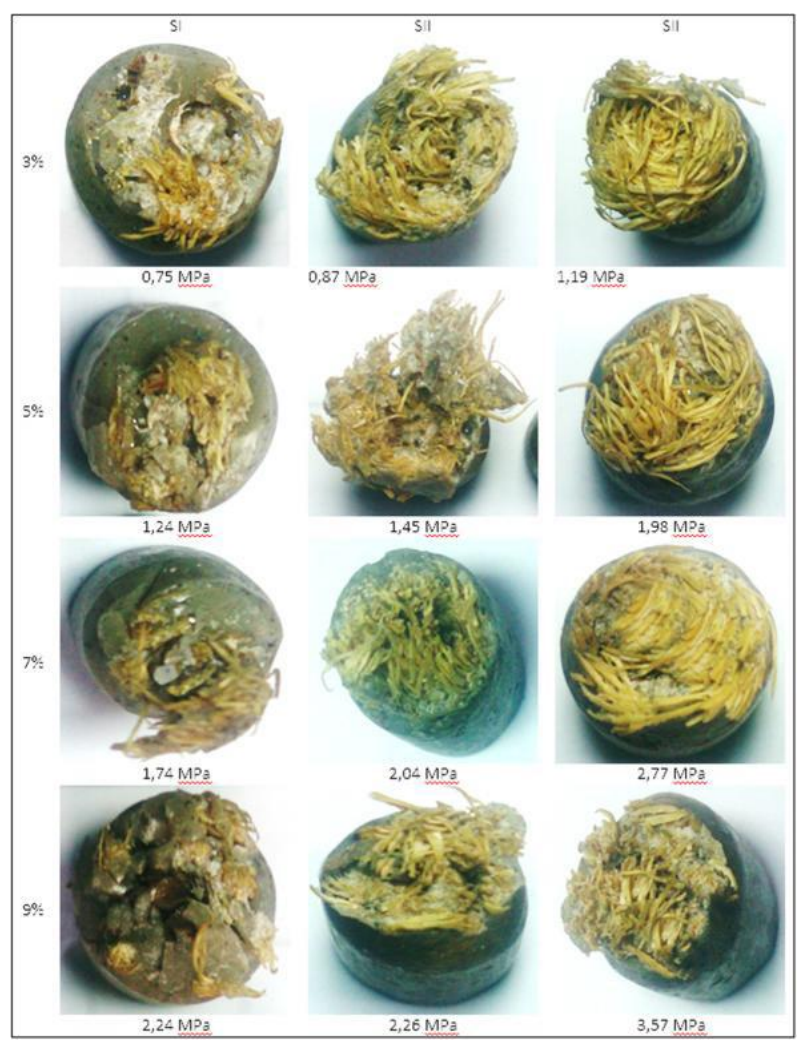

Gambar 14. Permukaan Patahan Seluruh Jenis Spesimen

Gambar 13 memperlihatkan bentuk patahan antar muka spesimen SIII dengan fraksi massa serat 30\% (3 gram) pada pembebanan $1,18 \mathrm{MPa}(0,41 \mathrm{~kg})$ gambar makro permukaan patahan memperlihatkan spesimen komposit setelah dilakukan pengujian, dimana pada patahan jelas terdapat patah berserabut, pada spesimen SIII ini juga terlihat jelas orientasi serat yang terpuntir (berputar) setelah terjadi patahan, sedangkan untuk zona patahan getas tidak terlihat jelas hal ini dapat dikaitkan dengan semakin banyak jumlah serat dan penyebaran serat pada spesimen SIII ini.

Gambar 14 memperlihatkan antar muka patahan dari seluruh variasi spesimen dari seluruh pembebanan yang diberikan, dari gambar terlihat bahwa perbedaan antar muka dari seluruh spesimen terlihat jelas dari segi komposisi serat yang gunakan serta pembebanan yang diberikan sangat berpengaruh kepada bentuk patahan yang terbentuk.

\section{KESIMPULAN}

Dari hasil pengujian kekuatan lelah Serat Tandan Kosong Kelapa Sawit dapat diperoleh kesimpulan sebagai berikut:

1. Peningkatan kekuatan lelah sebanding dengan peningkatan massa serat yang terkandung didalam komposit berserat tandan kosong kelapa sawit. Fatik limit tertinggi dimiliki oleh spesimen dengan fraksi serat paling besar (30\%) yaitu sebesar 0.82 MPa.

2. Umur lelah yang dapat dicapai oleh komposit TKKS dari semua variasi pengujian berkisar antara $10^{4}-10^{5}$ siklus dan untuk umur $>10^{6}$ siklus merupakan batas kekuatan lelah (fatik limit) dari spesimen komposit TKKS.

3. Semakin besar fraksi massa serat TKKS dalam komposit maka bentuk patah getas akan sangat sedikit sehingga penjalaran retak akan terhambat oleh struktur serat yang ada.

\section{UCAPAN TERIMA KASIH}

Penulis mengucapkan terima kasih kepada Jurusan Teknik Mesin Fakultas Teknik Universitas Andalas atas dukungannya melalui kontrak penelitian No. 060/UN16.09.D/PL/2017.

\section{DAFTAR PUSTAKA}

[1] Y. Hartono. Analisa Teknis Kekuatan Mekanis Material Komposit Berpenguat Serat Ampas Tebu (Baggase) ditinjau dari Kekuatan Tarik dan Impak, Tugas Akhir, Program Studi Perkapalan, Fakultas Teknik, Universitas Diponegoro Semarang, 2008.

[2] D. Gasni. Kapita Selekta Konstruksi Mesin B "Kriteria Patah Lelah Untuk Beban Dinamik" (TEM 426). Diktat Kuliah, Jurusan Teknik Mesin, Fakultas Teknik, Universitas Andalas: Padang, 2002.

[3] W. D. Callister. Materials Science and Engineering: An Introduction. John willey \& sons Inc: New York. 2007.

[4] G. E. Dieter. Mechanical Metallurgy, Third Edition. McGraw-Hill Book Company: New York, 1986 
[5] A. Esastra. Pengembangan Kampas Rem Sepeda Motor Dari Komposit Serat Tandan Kosong Kelapa Sawit, Kalsium Karbonat, Serbuk Aluminium Dengan Pengikat Resin Polyester. Tugas Akhir, Jurusan Teknik Mesin, Fakultas Teknik, Universitas Andalas: Padang, 2015.

[6] A. Haque A, and M. Rahman. Durability and Damage Development in Woven Ceramic Matrix Composites Under Tensile and Fatigue Loading at Room and Elevated Temperatures. www.materialstechnology.asmedigitalcollecti on. asme.org/article.aspx?articleid $=1426285$

[7] H. Ogawa. An Analysis on Surface Crack Growth under Rotary Bending Fatigue in Terms of Fracture Mechanic. Nihon Kikai Gakkai Ronbushu, A Hen/Transaction of the Japan Society of Mechanical Engineers: Japan, 1991.

[8] U. A. Khashaba. Fatigue and Reliability Analysis of Unidirectional GFRP Composites under Rotating Bending Loads. Journal. Mechanical Design and Production Engineering, Faculty of Engineering, Zagazig University, Zagazig, Egypt, 2001
[9] Haftirman. Fatigue Strength of Steel in High Humidity Environment. Transaction of the Japan Society of Mechanical Engineers: Japan, 1995.

[10] F. H. M. Alaya. Pengaruh kedalaman Takik Ulir Metris Terhadap Kekuatan Lelah Baja Karbon Rendah. Skripsi Jurusan Teknik Mesin, Fakultas Teknik, Universitas Negeri Semarang, Semarang, 2007.

[11] L. Reylan. Pengaruh Lama Waktu Perlakuan Alkali Terhadap Kekuatan Bending Komposit Papan Serat Tandan Kosong Kelapa Sawit. Tugas Akhir, Jurusan Teknik Mesin, Fakultas Teknik, Universitas Andalas, Padang, 2014.

[12] Alisa et.al. Time dependent fatigue crack growth behavior of silica particle reinforced epoxy resin composite, International Journal of Fatigue, 2016

[13] Bizeul et.al. Fatigue crack growth in thin notched woven glass composites under tensile loading. Composites Science and Technology, 2011. 